\section{Development of Tuber Blight (Phytophthora infestans) on Potato Cultivars Based on In Vitro Assays and Field Evaluations}

\author{
Richard O. Nyankanga \\ University of Nairobi, Department of Plant Science and Crop Protection, \\ P.O. Box 30197, Nairobi, Kenya
}

Ocen Modesto Olanya ${ }^{1}$

USDA-ARS, New England Plant, Soil and Water Laboratory, University of

Maine, Orono, ME 04469

\author{
Hans C. Wien \\ Cornell University, 156 Plant Sciences, Ithaca, NY 14853
}

Ramzy El-Bedewy

Agricultural Research Center, Kafr-El-Zayat, Egypt

John Karinga

National Potato Research Center, Tigoni, P.O. Box 338, Limuru, Kenya

Peter S. Ojiambo

Department of Plant Pathology, North Carolina State University, Raleigh, NC 27695

Additional index words. Phytophthora infestans, US-1 genotype, Solanum tuberosum, R-genes, tuber blight, tuber blight prediction

\begin{abstract}
Tuber blight may result from infection of wounded or unwounded potato tubers exposed to sporangia from foliar blight, soil, or blighted tubers. However, there are limited data on the prediction of tuber blight in field or storage environment based on in vitro assays. To assess this relationship, potato cultivars with foliar blight resistance ( $R$ genes) and general resistance were evaluated for tuber blight incited by Phytophthora infestans (US-1) based on wound-induced and unwounded tuber inoculations. Surface lesion diameter, lesion depth, and frequency distribution of blighted tubers were assessed in in vitro assays and tuber blight incidence determined in field experiments. Significant differences $(P<0.05)$ in lesion diameter and depth were recorded among cultivars. Surface lesion diameter, depth, and index ranged from 5 to 40, 2 to 16.3 , and 15 to 656 $\mathrm{mm}$, respectively, in wound-inoculated tubers. In nonwounded tuber assays, the incidence of blighted tubers ranged from $0 \%$ to $8.7 \%$ in both years. Tuber blight infection of potato cultivars varied between years in field studies. Although tuber infection differed among cultivars, the frequency of blighted tubers had a normal statistical distribution irrespective of R-genes, implying that foliar resistance may have limited effect on tuber blight occurrence based on in vitro experiments. Prediction of tuber blight based on inoculation assays can be effectively used to estimate and manage blight development in storage environments.
\end{abstract}

Late blight, caused by Phytophthora infestans (Mont.) de Bary, accounts for significant losses in potato production worldwide (Erwin and Ribeiro, 1996). The

pathogen infects foliage and tubers resulting in tuber yield loss attributable to premature death of the potato plant and tuber rot in the field and storage. Tubers become infected

\footnotetext{
Received for publication 30 Jan. 2008. Accepted for publication 6 Apr. 2008.

We are grateful to the Rockefeller Foundation for partially funding this research as part of the first author's $\mathrm{PhD}$ dissertation at Cornell University. We thank the International Potato Center (CIP, Nairobi) and National Potato Research Center (Tigoni, Kenya), and the USDA-ARS, New England Plant, Soil and Water Laboratory for technical and logistical support.

Mention of trade names or commercial products in this publication is solely for the purpose of providing specific information and does not imply recommendation for endorsement by the U.S. Department of Agriculture, University of Nairobi, Cornell University, Agric. Res. Center, the National Potato Research Center, or North Carolina State University.

${ }^{1}$ To whom reprint requests should be addressed; e-mail modesto.olanya@ars.usda.gov
}

when sporangia produced on leaf and stem lesions are washed into the soil (Lacey, 1967). In vitro tuber blight development may occur through occasional tuber abrasion during harvest or incidental wounding if diseased tubers or sporangia of $P$. infestans come into contact with nonwounded tubers. Tuber blight infection through lifting of tubers during harvest has also been well documented (Lapwood, 1977). Similarly, abrasion of tubers after harvest (Lambert et al., 1998) or wounds created by insects such as potato tuber moth or pathogen infections by bacterial soft rot (Pectobacterium carotovora) may also induce wounds and rot in tubers, which may additionally be exposed to tuber blight (Nyankanga et al., 2007).

Fungicide applications to control foliar late blight and vine kill using desiccants before harvest are the most common methods for reducing tuber infection (Cooke and Little, 2002; Stevenson, 1993). Based on this method of disease control, the relationships between levels of foliar blight and incidences of tuber blight have been reported to vary. Some authors have reported low incidence of tuber blight at harvest in the apparent absence of foliar blight (Lacey, 1967). In other cases, low incidence of tuber blight has been reported after high levels of foliar blight (Nyankanga et al., 2007; Olanya et al., 2006). Similarly, research reports have indicated high levels of tuber infection even in fields where numerous applications of protectant and curative fungicides were applied (Flier et al., 1998). In some field experiments, researchers have also suggested greater foliar and tuber blight attributed to aggressive strains (US-8) of $P$. infestans on potato tubers (Flier et al., 1998; Fry and Goodwin, 1997; Kirk et al., 2001). In the highland tropics of East Africa where the US-1 genotype of $P$. infestans has been reported (Vega Sanchez et al., 2000), variable occurrence of tuber blight has been reported (Nyankanga et al., 2007; Olanya et al., 2006). Although considerable research on cultivar differences, fungicide effects, and host resistance factors on foliar and tuber blight has been conducted (Flier et al., 1998; Olanya et al., 2006; Platt and Tai, 1998), few studies have explored the dynamics of tuber susceptibility or resistance to late blight in tropicaladapted potato cultivars.

In tropical regions, host-plant resistance to $P$. infestans has often been viewed as the most promising strategy for optimum management of late blight and sustainable production of potatoes in resource-constrained cropping systems (Wastie, 1991). Resistance to $P$. infestans on foliage has been recognized as specific (R-genes, which confer resistance to $P$. infestans isolates with the corresponding avirulence genes) and rate-reducing or general resistance, which limits the pathogen development on the host (Umaerus and Umaerus, 1994). Resistance in potato tubers is characterized by decreased pathogen penetration of the tuber tissue or reduction in pathogen colonization by localization of the pathogen in the infected tissue. The defense mechanisms in the epidermal, outer cortical, 
lenticel, eyes, or vascular regions of the tubers have been implicated in tuber blight development (Glass et al., 2001; Phatak and Clarke, 1987). Potato cultivars may differ in their level of resistance to tuber and foliar blight in one of these components. However, most of the potato cultivars grown in the tropical climate of Kenya have low to moderate levels of foliage resistance (El-Bedewy et al., 2001; Olanya et al., 2006). There is lack of quantitative data on in vitro tuber blight development in relation to field tuber infection of tropical-adapted cultivars and clones. This information can be used to determine whether tuber blight assessed from in vitro assays can be used to predict tuber blight infections under field conditions. Therefore, the objective of this study was to determine the reaction of tropical-adapted potato cultivars and advanced breeding lines to in vitro tuber blight development incited by $P$. infestans (US-1) and assess its relationship to foliar blight development and tuber infection under field conditions.

\section{Materials and Methods}

Germplasm selection. Twenty-eight cultivars and advanced lines were selected for evaluation in 2000 and 2001. The advanced lines were selected from the germplasm maintained by the International Potato Center (CIP) regional office in Kenya on the basis of promising agronomic characteristics, including adaptation to local conditions. Cultivars were potato cultivars currently grown by farmers in Kenya for either subsistence or commercial production. The cultivars included some carrying R-genes and some with quantitative resistance. The presence or absence of major late blight resistant genes (R-genes) was based on published data on CIP germplasm (El-Bedewy et al., 2001; Landeo et al., 1995; Landeo and Turkensteen, 1989).

Cultivars were grown from clean seed at the CIP's field sites at the CIP field sites at Kabete and Loreto. All standard agronomic practices were followed according to the local conditions. One to 2 weeks before harvest, vines were hand-cut and removed from the field. Tubers were hand-harvested and sorted into three categories: ware, seed, and rejects. Healthy, medium-sized tubers were selected and stored for 1 to 2 months in cold storage maintained at $5{ }^{\circ} \mathrm{C}$ before being used for tuber inoculation.

Inoculum preparation. Isolates for tuber inoculation were collected from fields around CIP testing sites and from western and eastern parts of the country. An isolate of $P$. infestans (1724, US-1, A1 mating type) was used for all inoculations (Mukalazi et al., 2001). Isolate of $P$. infestans was grown on Rye B medium (Caten and Jinks, 1968) amended with antibiotics and incubated at $15{ }^{\circ} \mathrm{C}$ in a temperature chamber for $14 \mathrm{~d}$. Sporangia were harvested by washing the Rye-B plates gently with distilled water and scraping the surface of the plate gently to dislodge the sporangia. The inoculum was then adjusted to $1.5 \times 10^{4}$ sporangia/mL using a hemacytometer. To stimulate zoospore release, the inoculum was stored at $4{ }^{\circ} \mathrm{C}$ for at least $1 \mathrm{~h}$ before tuber inoculation.

Whole tuber inoculation with $\mathrm{P}$. infestans. To estimate the different levels of resistance to tuber infection as a result of the lenticels, eyes, and periderm, whole tuber inoculation assay was used. Forty medium-sized tubers were selected for genotype. Care was taken to select uniform tubers to be of nearly the same surface area. Tubers were thoroughly washed using $0.5 \%$ commercial chlorox (sodium hypochlorite), rinsed twice with sterile distilled water, and blotted with tissue paper and left to dry completely. Ten tubers were placed in a plastic bag. There were four replications of 10 tubers for each cultivar or clone. Tubers in each plastic bag were uniformly sprayed with inoculum using a hand sprayer with low pressure to ensure that all tubers were covered with inoculum. The control treatments were sprayed with distilled water.

After treatment, inoculated tubers were incubated in an incubator maintained at $15{ }^{\circ} \mathrm{C}$ for 3 weeks. In the first 1 to $2 \mathrm{~d}$, tubers were maintained at $98 \%$ to $100 \%$ relative humidity (RH) by enclosing them in moistened plastic containers. Subsequently, tubers were maintained at $85 \%$ RH. After 3 weeks, tubers were examined for presence or absence of tuber blight symptoms and the number of tubers infected for each cultivar or clone was recorded. The percentage of infected tubers was calculated as an indicator of periderm, lenticel, and eye resistance. Infected tubers were then cut longitudinally and rated for severity using 0 to 5 as suggested by Bjor (1987) and modified by Flier et al. (1998) where $0=$ no symptoms on the cut surface; $1=2.5 \%$ or less of cut have symptoms; $2=2.5 \%$ to $10 \%$ of cut area with symptoms; $3=10 \%$ to $25 \%$ of cut area with symptoms; $4=25 \%$ to $50 \%$ of the cut area with symptoms; and $5=50 \%$ or greater of the cut area with symptoms.

Inoculation of wounded tubers with $\mathrm{P}$. infestans. Tubers of potato cultivars and clones were wounded by a cork-borer before inoculations to assess the resistance of cortex tissues to blight infection. Tubers were prepared as outlined previously and six tubers per cultivar were wounded at the stolon end and the rose end using a cork borer. The wounds were $2 \mathrm{~mm}$ diameter and $2 \mathrm{~mm}$ deep. The wounds were inoculated using two droplets of $10 \mu \mathrm{l}$ each of inoculum suspension described previously and then allowed to stand for $10 \mathrm{~min}$. The controls were inoculated using two drops of distilled water. Tubers were then placed in plastic bags using three tubers per bag. The plastic bags were placed in plastic containers. Each genotype had four replications of six tubers each. Each plastic container was treated as a block. The tubers were incubated as outlined for the unwounded assay. After 3 weeks, the diameter of lesion expansion was measured by measuring the sunken lesion. The diameter of lesions was used as an indicator of the resistance of the storage tissue, the medulla. Tubers were then cut longitudinally and the penetration of the pathogen was estimated by measuring the depth of the lesions.

Effects of cultivars and pathogen isolates on lesion development. Development of tuber blight on tubers of potato cultivars was assessed on in vitro assays of tubers. Tubers from four cultivars, Awash and Rutuku (both with R-genes) and Genet and Tigoni (both with quantitative resistance), were inoculated with $P$. infestans isolates of US-1 genotype (isolates 1006, 1724 and 1017) and incubated at $15^{\circ} \mathrm{C}$. The experiment was arranged as $4 \times$ 3 factorial (cultivar $\times$ pathogen isolate) in a completely randomized design with three replications. Surface lesion development was quantified by measuring lesion diameter at 2-d intervals.

Evaluation of foliar and tuber blight incidence in field experiments. Experiments were established at two locations, Loreto $(2100 \mathrm{~m})$ and Kabete $(1800 \mathrm{~m})$, during the 2001 and 2002 cropping seasons. Soils at the two experimental sites are typically humic nitosols, acid soils with a thick layer of clay accumulation (Jaetzold and Schmidt, 1982). Potato is often severely infected by $P$. infestans throughout the year at these two sites and thus cultivars were evaluated under natural infection. Field plots were laid out in a randomized complete block design with three replications. Field plots consisted of two rows each containing 20 tubers with spacing of $75 \mathrm{~cm}$ and $30 \mathrm{~cm}$ between rows and tubers, respectively. Normal agronomic practices for potato production were followed. Insecticide (metasystox; Bayer East Africa Ltd., Nairobi, Kenya) was applied as needed for aphid control. No fungicides were applied to the field plots and natural blight infection was established. Field plots were assessed for late blight development by visual rating of foliage for percent leaf area blighted (disease severity) beginning from the time when $2 \%$ to $5 \%$ leaf area blight was observed on the susceptible, control cultivar. Subsequent evaluations of percentage disease severity were recorded weekly until severity on the most susceptible cultivar approached $100 \%$. Tuber blight (percent) in the field was assessed at harvest by recording the number of tubers with typical symptoms for each cultivar and plot.

Statistical analysis. Diameter and depth of lesions at both the stolon and rose ends were averaged for each tuber before analyses. Percentage of infected tubers was arc square root-transformed before analysis to stabilize the variances. All data were analyzed by analysis of variance. In case of significant differences, means were separated using Fisher's least significant difference test. Foliar blight severity assessed in field plots was used to calculate area under disease progress curves (AUDPC - $\%$ disease days). The association among the different components of resistance to tuber blight infection based on in vitro assays and field evaluation was assessed using correlation analysis using PROC CORR in SAS version 9.1 (SAS 
Table 1. Analysis of variance for whole tuber, wounded tuber, and field assays comparing different cultivars and advanced clones for infection by Phytophthora infestans in Kenya.

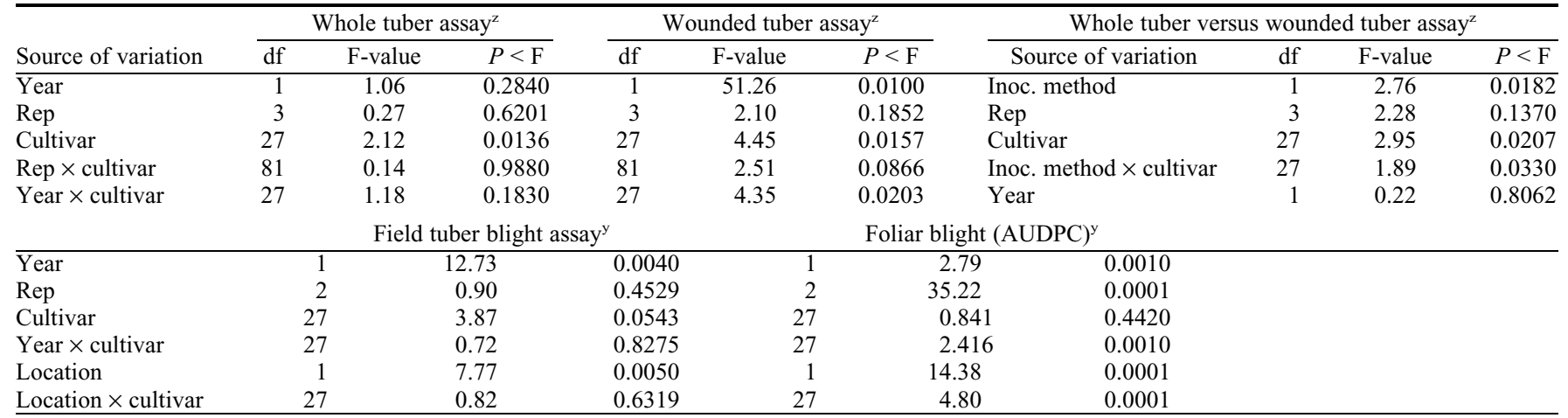

${ }^{2}$ Laboratory in vitro tests were conducted in 2000 and 2001, whereas ${ }^{y}$ field tests were done in 2001 and 2002 using 28 cultivars and advanced clones.

AUDPC $=$ area under disease progress curves.

Institute, Cary, NC). Associations of tuber blight resistance parameters based on in vitro assays (lesion diameter, depth, and index) as well as between cultivars with R-genes and general resistance were compared by correlation analysis. The distribution of tuber surface lesion and depth were made by frequency histograms. Estimation of tuber blight development in the field based on in vitro assays was evaluated using linear stepwise regression analysis of tuber blight as a function of lesion diameter, lesion depth, lesion index (wound-induced inoculation experiments), tuber blight incidence, tuber blight severity (unwounded tuber inoculation experiments), and foliar AUDPC (field experiments). Similarly, estimation of tuber blight development for cultivars with R-genes and general resistance were also assessed using regression analysis.

\section{Results}

Whole unwounded tuber assay. There were significant differences $(P<0.05)$ in overall tuber blight incidence among cultivars (Tables 1 and 2). Variation in tuber blight incidence among cultivars was observed in both years (Table 2). The average incidence of tuber blight ranged from $0 \%$ to $8.3 \%$ in 2000 and from $0 \%$ to $13.8 \%$ in 2001 . Little variation in tuber blight severity among cultivars was detected. Four advanced selections, 391049.27, 392165.62, 392622.61, and 392640.22 , and the cultivar Rutuku showed very low tuber blight infection when subjected to sporangia inoculation in both years (Table 2).

Wounded tuber assay. Significant differences $(P<0.05)$ in tuber blight levels were observed among cultivars (Tables 1 and 3 ). Analysis also revealed significant year-bycultivar interactions (Table 1). Variation in lesion diameter (surface necrosis), lesion depth, and lesion index (pathogen penetration index) were recorded (Table 3 ). The cultivars 392640.2, 391049.3, 392637.7, and 392640 had lower overall tuber blight incidence than other commercial cultivars as indicated by the tuber blight lesion index. Among the cultivars tested, Kerr's Pink was the most

Table 2. Infection of potato tubers after inoculation of whole surface tubers with sporangia suspension of Phytophthora infestans (US-1) in controlled experiments at $15^{\circ} \mathrm{C}$.

\begin{tabular}{|c|c|c|c|c|}
\hline \multirow[b]{2}{*}{ Clone/cultivar } & \multicolumn{2}{|c|}{2000} & \multicolumn{2}{|c|}{2001} \\
\hline & $\begin{array}{l}\text { Tuber blight } \\
\text { incidence }(\%)^{z}\end{array}$ & $\begin{array}{c}\text { Tuber blight } \\
\text { severity }(\%)^{\mathrm{y}}\end{array}$ & $\begin{array}{c}\text { Tuber blight } \\
\text { incidence }(\%)^{z}\end{array}$ & $\begin{array}{c}\text { Tuber blight } \\
\text { severity }\end{array}$ \\
\hline KP90164.31 & 5.0 & 0.9 & 3.8 & 0.7 \\
\hline 392640.28 & 3.3 & 0.7 & 7.5 & 1.5 \\
\hline KР93734.12 & 1.6 & 0.4 & 1.3 & 0.3 \\
\hline 390381.32 & 1.5 & 1.1 & 5.3 & 1.2 \\
\hline 392640.21 & 5.0 & 1.0 & 8.8 & 1.4 \\
\hline 392165.62 & 0.0 & 0.0 & 0.0 & 0.0 \\
\hline 392622.24 & 3.3 & 0.4 & 7.5 & 0.4 \\
\hline 392143.44 & 1.5 & 1.0 & 1.3 & 1.0 \\
\hline 391049.27 & 0.0 & 0.0 & 0.0 & 0.0 \\
\hline KР9126.6 & 8.3 & 1.0 & 6.3 & 0.8 \\
\hline 387193.21 & 8.3 & 1.0 & 6.3 & 1.0 \\
\hline 392622.61 & 0.0 & 0.0 & 0.0 & 0.0 \\
\hline KР93743.6 & 6.6 & 1.5 & 9.0 & 1.6 \\
\hline KР91276.6 & 1.6 & 0.4 & 1.2 & 0.3 \\
\hline 392640.22 & 0.0 & 0.0 & 0.0 & 0.0 \\
\hline KР90185.2 & 6.6 & 1.0 & 10.0 & 1.3 \\
\hline 382119.13 & 3.2 & 0.3 & 2.5 & 0.3 \\
\hline 392618.14 & 6.0 & 1.4 & 9.0 & 1.8 \\
\hline KР90142.39 & 6.5 & 0.9 & 5.0 & 0.7 \\
\hline KP90121.1 & 1.6 & 0.4 & 6.3 & 0.4 \\
\hline 392637.73 & 2.5 & 1.1 & 4.4 & 1.3 \\
\hline 380456.1 & 3.7 & 1.2 & 2.5 & 0.8 \\
\hline Kerr's Pink & 6.7 & 1.4 & 10.0 & 1.5 \\
\hline Asante & 1.6 & 0.9 & 5.2 & 0.8 \\
\hline Tigoni & 10.1 & 1.0 & 13.8 & 1.3 \\
\hline Cruza 148 & 5.0 & 0.7 & 7.8 & 0.9 \\
\hline Dutch Robijn & 5.0 & 0.8 & 8.7 & 0.8 \\
\hline Rutuku & 0.0 & 0.0 & 4.0 & 0.0 \\
\hline Nyayo & 1.6 & 0.4 & 6.3 & 0.8 \\
\hline Mean & 3.6 & 0.7 & 5.2 & 0.8 \\
\hline $\operatorname{LSD}(\alpha=0.05)$ & 4.2 & - & 5.8 & - \\
\hline
\end{tabular}

${ }^{\mathrm{z}}$ Number of blighted tubers expressed as percentage of total tubers inoculated.

${ }^{\mathrm{y}}$ Based on a scale of 0 to 5 in which $0=$ no symptoms; $1=1 \%$ to $2.5 \% ; 2=2.5 \%$ to $10 \% ; 3=10 \%$ to $25 \%$; $4=25 \%$ to $50 \%$; and $5=$ greater than $50 \%$ of tuber surface covered by lesions of $P$. infestans.

susceptible as indicated by surface necrosis and also relatively deep penetration of the pathogen. The variation, however, among all the cultivars was considerable over the 2 years. In 2000, three selections 392637.7, 380456.1, and KP90142.39 and two cultivars Cruza 148 and Dutch Robijn showed high levels of resistance to tuber blight as indicated by tuber blight parameters. However, in 2002, selections 382119.1, 392640.2, and 391049.3 and cultivars Rutuku and Dutch Robijn showed moderate resistance to tuber blight infection.
The cultivars $392622.6, \quad 391049.3$ 382119.1, KP90121.1, and KP93743.6 had significantly $(P<0.05)$ higher surface spread of the pathogen. In general, apart from a few cultivars, higher surface necrosis was often followed by deep penetration of the pathogen. The observation of cultivar susceptibility based on the index differed slightly over the 2 years. In general, tuber infection was higher in the second year than the first year.

Effects of cultivar and pathogen isolate on lesion development. In vitro development of tuber blight increased linearly postinoculation 
with Phytophthora infestans (Fig. 1). The surface lesion growth on inoculated tubers differed significantly $(P<0.01)$ among cultivars (Table 4). The cultivars Awash and

Rutuku (both with R-genes) had significantly $(P<0.05)$ lower tuber blight lesion compared with Genet and Tigoni, which have general resistance to late blight (Fig. 1).

Table 3. Reaction of tubers of potato cultivars and advanced clones to Phytophthora infestans (US-1) after wounding and subsequent inoculation of tubers in vitro in 2000 and 2001.

\begin{tabular}{|c|c|c|c|c|c|c|}
\hline \multirow[b]{2}{*}{ Clone/cultivar } & \multicolumn{3}{|c|}{2000} & \multicolumn{3}{|c|}{2001} \\
\hline & $\begin{array}{c}\text { Lesion } \\
\operatorname{diam}(\mathrm{mm})^{\mathrm{z}}\end{array}$ & $\begin{array}{c}\text { Lesion } \\
\text { depth }(\mathrm{mm})^{\mathrm{y}}\end{array}$ & $\begin{array}{l}\text { Lesion } \\
\text { index }^{\mathrm{x}}\end{array}$ & $\begin{array}{c}\text { Lesion } \\
\operatorname{diam}(\mathrm{mm})^{\mathrm{z}}\end{array}$ & $\begin{array}{c}\text { Lesion } \\
\text { depth }(\mathrm{mm})^{\mathrm{y}}\end{array}$ & $\begin{array}{l}\text { Lesion } \\
\text { index }^{x}\end{array}$ \\
\hline$\overline{382119.1}$ & 14.0 & 12.0 & 168.0 & 20.1 & 3.0 & 60.3 \\
\hline 392640.2 & 16.5 & 4.0 & 66.0 & 32.7 & 2.0 & 65.4 \\
\hline 391049.3 & 22.3 & 5.7 & 127.1 & 20.3 & 4.9 & 99.5 \\
\hline KP90121.1 & 11.0 & 6.0 & 66.0 & 21.8 & 5.3 & 115.5 \\
\hline 392637.7 & 5.0 & 3.0 & 15.0 & 39.3 & 3.7 & 145.4 \\
\hline 390381.3 & 28.5 & 7.5 & 213.7 & 37.1 & 4.0 & 148.4 \\
\hline КР91276.6 & 28.0 & 9.0 & 252.0 & 26.2 & 6.3 & 165.1 \\
\hline Rutuku & 5.0 & 7.0 & 35.0 & 38.5 & 9.0 & 192.5 \\
\hline Dutch Robijn & 7.0 & 6.0 & 42.0 & 27.7 & 12.3 & 193.9 \\
\hline 392622.2 & 24.0 & 7.5 & 180.0 & 36.7 & 5.5 & 201.8 \\
\hline 392622.6 & 21.7 & 13.0 & 282.1 & 18.3 & 11.3 & 206.8 \\
\hline 380456.1 & 5.0 & 7.0 & 35.0 & 34.0 & 6.2 & 210.8 \\
\hline KP9126.6 & 22.1 & 10.0 & 221.0 & 25.7 & 8.4 & 215.9 \\
\hline КР90185.2 & 16.5 & 9.5 & 156.7 & 23.6 & 9.4 & 221.8 \\
\hline Nyayo & ${ }^{\mathrm{w}}$ & - & - & 38.5 & 6.2 & 238.7 \\
\hline KР90164.31 & 36.5 & 9.0 & 328.5 & 38.9 & 6.3 & 245.1 \\
\hline 392640.2 & 27.0 & 9.0 & 243.0 & 29.8 & 8.5 & 253.3 \\
\hline 392143.4 & 23.9 & 5.0 & 119.5 & 26.0 & 10.0 & 260.0 \\
\hline Asante & 15.5 & 9.0 & 139.5 & 39.0 & 11.0 & 269.1 \\
\hline Cruza 148 & 10.3 & 8.0 & 82.1 & 39.0 & 7.0 & 273.0 \\
\hline Tigoni & 14.5 & 10.0 & 145.0 & 38.2 & 11.0 & 305.6 \\
\hline KP93734.12 & 29.0 & 7.5 & 217.5 & 42.6 & 7.6 & 323.7 \\
\hline Kerr's Pink & 25.7 & 16.0 & 411.2 & 23.0 & 16.3 & 374.9 \\
\hline КР93743.6 & 20.0 & 10.0 & 200.0 & 22.5 & 17.0 & 382.5 \\
\hline 392165.6 & 25.6 & 15.5 & 396.8 & 30.3 & 12.8 & 387.8 \\
\hline 387193.2 & 22.0 & 7.0 & 154.0 & 31.1 & 13.0 & 404.3 \\
\hline 392640.3 & 39.3 & 3.0 & 117.9 & 36.3 & 13.7 & 497.3 \\
\hline 392618.1 & 12.0 & 17.5 & 210.0 & 44.6 & 11.3 & 503.9 \\
\hline KР90142.39 & 12.0 & 7.0 & 84.0 & 40.0 & 16.4 & 656.0 \\
\hline Mean & 19.28 & 8.60 & 168.16 & 32.92 & 8.94 & 262.70 \\
\hline $\operatorname{LSD}(\alpha=0.05)$ & 1.48 & 2.07 & - & 1.97 & 1.47 & - \\
\hline
\end{tabular}

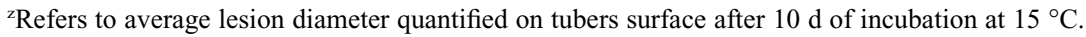
${ }^{y}$ Depth of tuber blight lesion was quantified after $4 \mathrm{~d}$ after incubation at $15{ }^{\circ} \mathrm{C}$.

${ }^{\mathrm{x}}$ Lesion index was calculated as lesion diameter $\times$ lesion depth. Means in a column followed by the same letter are significantly different $(P<0.05)$ based on Fisher's least significant difference test and wno data.

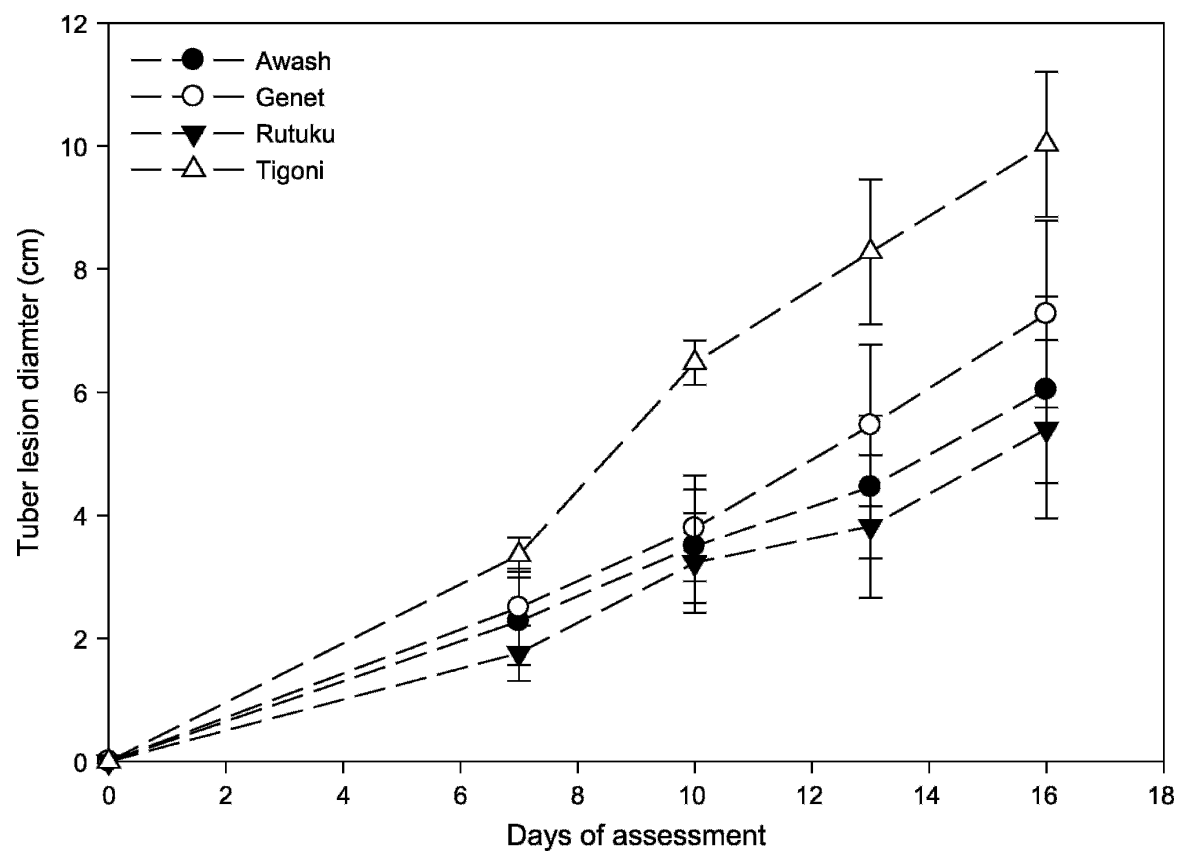

Fig. 1. Tuber blight development on potato cultivars inoculated with Phytophthora infestans (US-1 genotype). Awash and Rutuku are cultivars with major resistance (R) genes, whereas Tigoni and Genet have general or quantitative resistance to late blight.
Foliar late blight and tuber blight incidence in field experiments. At both locations, significant differences $(P<0.05)$ in AUDPC (foliar blight) were observed among cultivars and clones at both locations (Tables 1 and 5). Kerr's Pink, a susceptible cultivar (control), had significantly $(P<0.05)$ greater AUDPC than other cultivars in 2001 and 2002 (Table 5). Across locations, the average tuber blight infection in field experiments ranged from $0 \%$ to $8 \%$ at Kabete and from $0 \%$ to $3.7 \%$ at Loreto in 2001 . The corresponding levels of tuber blight infection in field experiments in 2002 ranged from $0 \%$ to $1 \%$ at Kabete and $0 \%$ to $13.8 \%$ at Loreto. Generally, low incidence of tuber blight was recorded at Kabete compared with the Loreto location in both years (Table 5).

Association among different components of tuber resistance based on in vitro and field measurements. An increase in lesion diameter tended to be associated with an increase in depth of lesion $(r=0.46, P<0.05)$. The association between field evaluation for blight severity and tuber blight data based on in vitro tuber assay was not significant (Table 6). Frequency histograms of tuber blight parameters such as lesion depth and surface lesion diameter showed normal distribution with skewness toward susceptibility irrespective of the parameters compared as well as the presence or absence of R-genes in cultivars (Fig. 2).

Estimation of tuber blight occurrence in field from tuber blight assessments based on in vitro assays. Estimation of tuber blight occurrence in field experiments from in vitro tuber assays did not show consistent results or significant disease prediction. Prediction of tuber blight in the field based on tuber lesion index, lesion depth, and lesion diameter from wound-induced in vitro inoculations resulted in low $R^{2}$ values (Table 7). Similarly, estimation of tuber blight based on tuber incidence and severity from unwounded inoculation assays did not result in significant prediction of tuber blight in field (Table 7). The combination of multiple variables resulted in moderate estimation of tuber blight and the presence of major or general resistant genes among cultivars had no significant effect on tuber blight predictions.

\section{Discussion}

The dynamics of infection of wounded and unwounded tubers is crucial for understanding resistance to tuber infection caused by Phytophthora infestans. This study documented a comparative analysis of in vitro tuber blight development on potato cultivars incited by $P$. infestans based on woundinduced inoculations and unwounded assays and assessed their relationship to foliar and tuber blight occurrence under field conditions. Although variations in components of tuber resistance was observed among potato cultivars, estimation of tuber blight occurrence in the field could not be reliably predicted from in vitro laboratory assays 
Table 4. Effect of cultivars and pathogen isolates on in vitro tuber blight development based on artificial inoculation with Phytophthora infestans at $15^{\circ} \mathrm{C}$.

\begin{tabular}{lrrr}
\hline Source & df & F-value & $P<\mathrm{F}$ \\
\hline Rep & 2 & 0.51 & 0.1100 \\
Cultivar & & 339.24 & 0.0010 \\
Rep $\times$ cultivar & 3 & 1.17 & 0.3264 \\
Isolate $^{y}$ & 6 & 865.37 & 0.0010 \\
Cultivar $\times$ isolate & 2 & 235.66 & 0.0010 \\
Assessment day (DOA) & 6 & 314.26 & 0.0200 \\
Isolate $\times$ DOA & 3 & 51.51 & 0.0240 \\
Cultivar $\times$ isolate $\times$ DOA & 6 & 12.92 & 0.0010 \\
\hline
\end{tabular}

${ }^{\mathrm{z} C u l t i v a r s ~ w e r e ~ R u t u k u ~ a n d ~ A w a s h ~(w i t h ~ R-g e n e s), ~ T i g o n i ~ a n d ~ G e n e t ~(w i t h o u t ~ R-g e n e s), ~ a n d ~ s u s c e p t i b l e ~}$ control (Kerr's Pink).

y Pathogen isolates 1006 and 1017 were characterized as US-1 genotype (A 1) mating type and isolated from potato fields in Kenya.

and may be attributed to infection process in laboratory assays and sterile environments compared with interactive events that could affect tuber blight occurrence in the field.

Differences in tuber resistance to blight infection under field conditions can be attributed to variation in the development of the periderm (Lapwood, 1977), lenticel resistance (Lacey, 1967), to tuber maturity (Grinberg et al., 1995) as well as inoculum load, soil environment, and microbial interactions (Andrivon, 1995; Nyankanga et al., 2007). These barriers are not present in woundinduced inoculations, although variation in tuber susceptibility was detected among cultivars. Therefore, the susceptibility of most cultivars to tuber blight based on in vitro inoculations may not be unexpected because the pathogen was introduced directly to tubers during the wounding process. Wounding removes resistance to tuber blight infection exhibited by epidermal, outer cortex, and vascular tissues (Phatak and Clarke, 1987). It is possible that assay of wounded tubers for blight development might have underestimated resistance of tubers from the various potato cultivars. Similar observations were made by Toxopeus (1958) and Flier et al. (1998) who noted that disease development was most rapid in susceptible tubers once the tubers had been penetrated (by wounding) and that tuber disease development can be high even in highly resistant cultivars because resistance components to pathogen penetration was not a factor in this study. Thus, this method may have obscured the true differences among the different cultivars.

Intact periderm has been shown to be a barrier to $P$. infestans penetration (Hirst et al., 1965; Phatak and Clarke, 1987). In our research, most of the infection of tubers occurred through the eyes and lenticels in whole unwounded tuber assay. In previous research, the resistance of the eyes and lenticels to tuber infection was observed to increase with plant or tuber maturity (Bjor, 1987). Tubers used in the unwounded assay were stored for 1 month before inoculation, which may allow for different stages of dormancy and suberization to occur depending on the earliness of the cultivars or cultivars. Therefore, tuber blight infection may have been influenced by the physiological conditions of the tubers used in these assays.

The presence of major resistant genes (R-genes) has been shown to increase resistance to foliar late blight infection in many potato cultivars (Toxopeus, 1958). There is no

Table 5. Tuber blight infection (\%) and area under disease progress curve (AUDPC - \% disease days) of potato clones and cultivars evaluated at Kabete and Loreto under natural blight infection Phytophthora infestans (US-1) in Kenya.

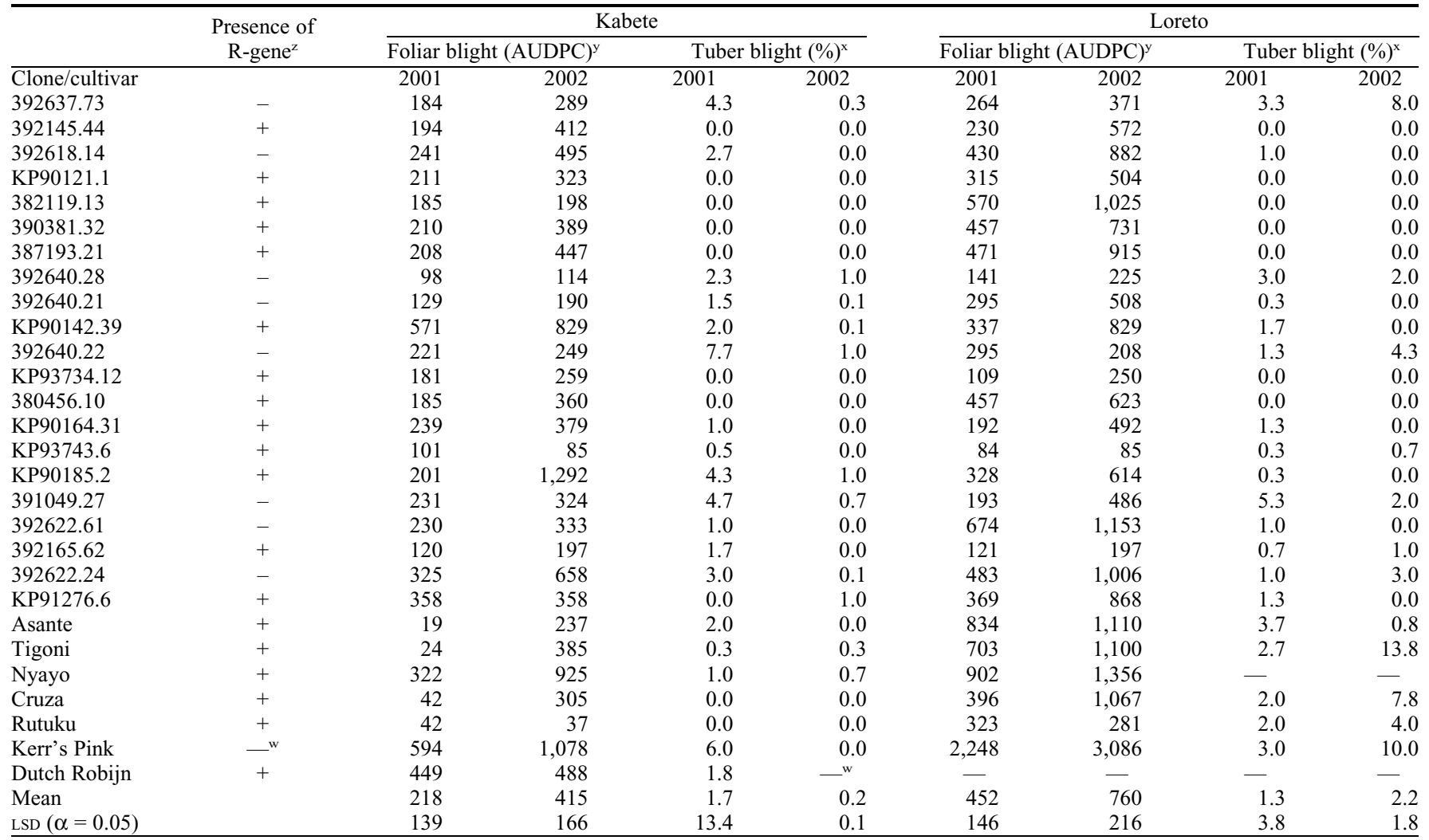

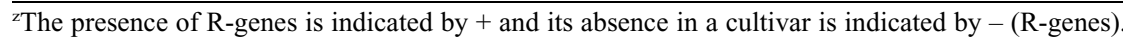

${ }^{y}$ AUDPC refers to percent disease days and calculated from foliar blight severity based on field assessments at two locations.

${ }^{\mathrm{x}}$ Refers to number of tubers blighted expressed as percentage of total tubers based on field evaluation at harvest.

wNo data.

AUDPC $=$ area under disease progress curves. 
Table 6. Pearson correlation coefficients among the assessment parameters used to quantify tuber blight (Phytophthora infestans) in unwounded and wounded tuber assays based on in vitro (laboratory) tuber inoculations.

\begin{tabular}{lcccc}
\hline Variables assessed & $\begin{array}{c}\text { Lesion } \\
\text { diam }(\mathrm{mm})\end{array}$ & $\begin{array}{c}\text { Lesion } \\
\text { depth }(\mathrm{mm})\end{array}$ & $\begin{array}{c}\text { Surface necrosis } \\
\text { (unwounded tubers) }\end{array}$ & $\begin{array}{c}\text { Foliage blight } \\
\text { rating }\end{array}$ \\
\hline Lesion diameter & - & $0.463^{\mathrm{y}}$ & $0.253^{\mathrm{z}}$ & $0.039 \mathrm{NS}$ \\
Lesion depth & - & - & $0.214^{\mathrm{z}}$ & $0.072 \mathrm{NS}$ \\
$\begin{array}{l}\text { Surface necrosis } \\
\quad \text { (unwounded tubers) }\end{array}$ & - & - & - & $-0.005 \mathrm{NS}$ \\
\hline
\end{tabular}

${ }^{\mathrm{z}}$ and ${ }^{\mathrm{y}}$ indicate significant test at $P=0.05$ and 0.01 , respectively, and Ns indicates no significant differences.
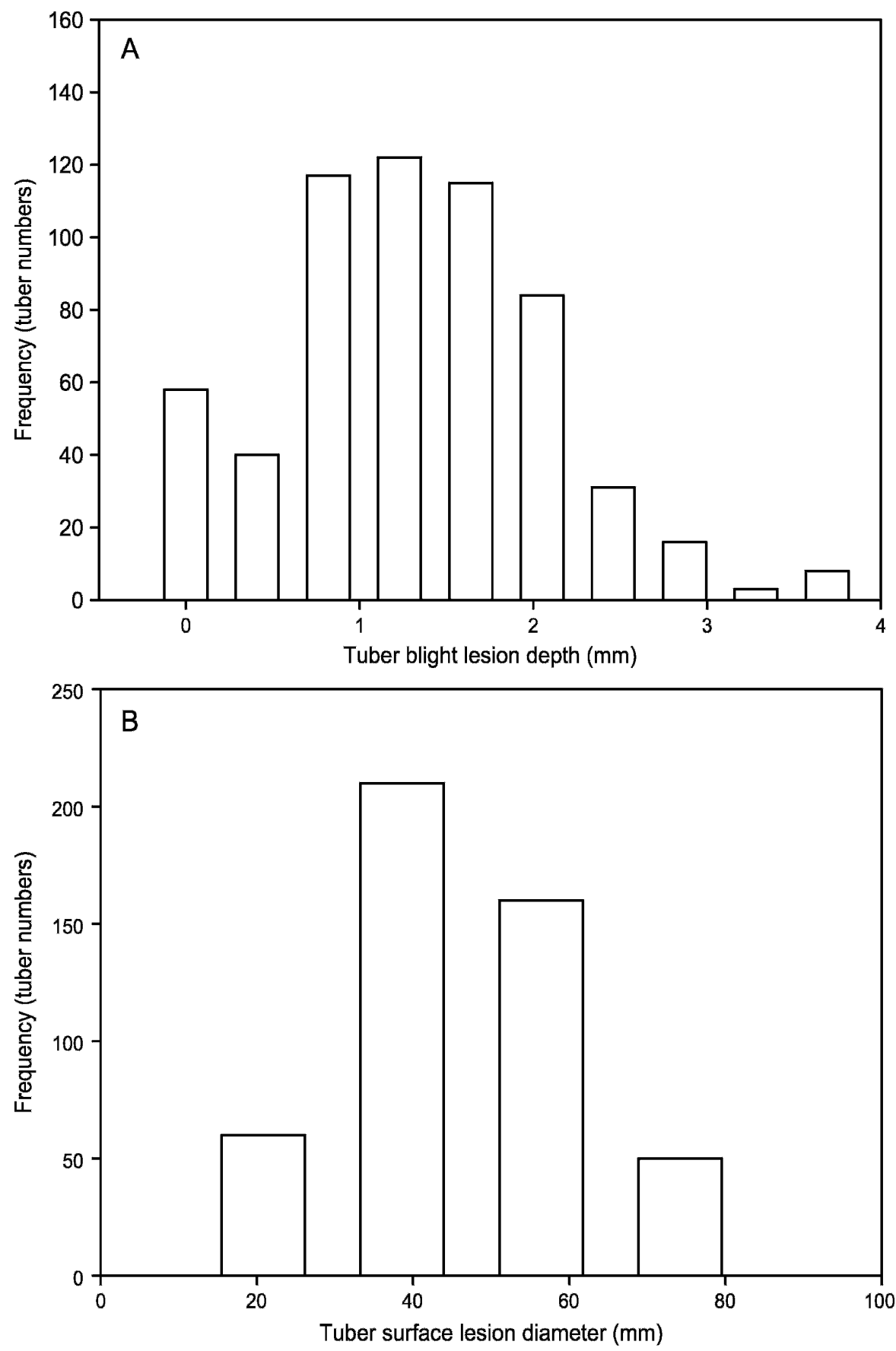

Fig. 2. Frequency distribution of lesion depths (millimeters) on tubers inoculated by Phytophthora infestans (US-1 genotype) based on wounded tuber assays in 2000 and 2001 data (A) and frequency distribution of surface lesion diameter (millimeters) for tubers infected after wound inoculation assay (B). evidence from our study regarding the significance of R-genes to tuber blight resistance incited by US-1 genotype of $P$. infestans. Although cultivars with R-genes often show hypersensitive response or very high resistance to foliage blight, the same reactions were not observed in tuber inoculation assays. Similarly, our results also indicate that frequency histogram of blighted tubers showed nearly normal distribution, indicating the lack of significance of R-genes or their absence in tuber blight occurrence among cultivars.

This research showed that there was a positive association between tuber blight surface lesion necrosis and penetration of the pathogen. This agrees with the research results of Peters et al. (1999), who found that necrotic lesion area tended to coincide with increase in pathogen penetration into the tuber. However, it should be noted that although this association was significant; some of the cultivars showed a deviation from this trend. In general, the association among different components (lenticels, periderm, and eyes) of tuber resistance and foliage blight ratings was not significant. As shown by Flier et al. (2001), there appears to be different genetic systems governing resistance against late blight in tubers and foliage blight resistance and perhaps between the different components of tuber resistance.

Environmental conditions have been shown to influence the level of tuber infection by $P$. infestans. Parker et al. (1992) in their study of stability of disease expression found that after inoculation with three isolates of $P$. infestans, the cultivar Alpha had a different ranking in Toluca, Mexico, than in New York, NY. They concluded that different environmental conditions might have exerted a great influence on the disease values and cultivar rankings. Similarly, Stewart et al. (1994) found that the environmental component of variation was greater for tuber blight than for foliage blight. In our studies, the variation in tuber blight detected between the locations and years may be attributed to environmental influence on disease levels (inoculum load) and subsequently tuber blight. Differences in soil environment and microbes between locations could also lead to variation in tuber blight even with the same disease conditions or inoculum load at the two locations.

In both years of this study, there was no significant association between levels of tuber blight under in vitro assays and field infection. It has been reported that some cultivars with low field infection have shown higher infection in in vitro testing (Dorrance and Inglis, 1998). This may be the result of plant architecture, especially on tuber placement in the hills. Also, tuber infection in the field is affected by many factors such as timing of foliar infection, distribution of inoculum, timing and amount of rainfall, and soil temperatures (Nyankanga et al., 2007). In general, wound-induced tuber blight inoculations and unwounded tuber assays for blight intensity would be very 
Table 7. Linear regression equations for estimation of tuber blight severity caused by Phytophthora infestans (US-1 genotype) in field experiments based on wound-induced and sporangia suspension inoculations from in vitro assays.

\begin{tabular}{|c|c|c|}
\hline \multirow[b]{2}{*}{ Variables $^{2}$} & Regression equation $^{y}$ & $R^{2 \mathrm{x}}$ \\
\hline & \multicolumn{2}{|c|}{ Using lesion index, lesion diameter, lesion depth, blighted tuber, and blight severity on tubers and AUDPC } \\
\hline \multirow{3}{*}{ Tuber blight severity (all cultivars) } & $\mathrm{TB}=0.53+0.021 \mathrm{AUD}$ & $0.20 \mathrm{NS}$ \\
\hline & $\mathrm{TB}=3.29+0.024 \mathrm{LIN}-0.15 \mathrm{LDI}-0.30 \mathrm{LDE}$ & $0.35 \mathrm{NS}$ \\
\hline & $\mathrm{TB}=0.66+0.41 \mathrm{TBI}-0.90 \mathrm{SEB}$ & $0.16 \mathrm{NS}$ \\
\hline \multirow{3}{*}{$\begin{array}{l}\text { Tuber blight severity } \\
\text { (cultivars with R-genes) }\end{array}$} & $\mathrm{TB}=0.13+0.034 \mathrm{LDI}+0.03 \mathrm{LDE}$ & $0.17 \mathrm{NS}$ \\
\hline & $\mathrm{TB}=0.37+0.28 \mathrm{TBI}-0.99 \mathrm{SEB}$ & $0.33 \mathrm{NS}$ \\
\hline & $\mathrm{TB}=1.39-0.00042 \mathrm{AUD}$ & $0.10 \mathrm{NS}$ \\
\hline \multirow{3}{*}{$\begin{array}{l}\text { Tuber blight severity (cultivars with } \\
\text { general resistance) }\end{array}$} & $\mathrm{TB}=2.21-0.02 \mathrm{LIN}+0.06 \mathrm{LDI}+0.04 \mathrm{LDE}+0.33 \mathrm{TBI}-1.26 \mathrm{SEB}$ & $0.33 \mathrm{NS}$ \\
\hline & $\mathrm{TB}=2.64-0.02 \mathrm{LIN}+0.04 \mathrm{LDI}+0.02 \mathrm{LDE}$ & $0.23 \mathrm{NS}$ \\
\hline & $\mathrm{TB}=4.21-0.05 \mathrm{LDI}-0.20 \mathrm{LDE}$ & $0.15 \mathrm{NS}$ \\
\hline
\end{tabular}

${ }^{\mathrm{z}}$ Tuber blight incidence in field estimated from tuber blight incidence in in vitro assays.

${ }^{\mathrm{y}} \mathrm{TB}=$ tuber blight severity; $\mathrm{LIN}=$ lesion index; $\mathrm{LDI}=$ lesion diameter; $\mathrm{LDE}=$ lesion depth; TBI = tuber blight incidence from unwounded tubers based on in vitro inoculations; SEB = tuber blight severity from unwounded tubers based on in vitro inoculations; and AUD = area under disease progress curve (AUDPC, percent disease days) calculated from foliar blight severity assessed from field experiment.

${ }^{\mathrm{x}}$ Coefficient of determination.

"Refers to significant coefficients at $P<0.05$.

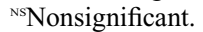

useful for estimation of blight occurrence and development in storage environments and possible interaction with other microbes at designated humidity and temperature settings.

In conclusion, this study showed that tuber blight resistance exists in both commercial cultivars and advanced potato clones. However, the high variations in tuber blight observed between years and among cultivars suggest variation in environmental conditions, inoculum load, or susceptibility of cultivars. Components of tuber resistance from in vitro assays may have limited use for tuber blight prediction in field assays based on our data, but useful for tuber blight estimation in storage environments.

\section{Literature Cited}

Andrivon, D. 1995. Biology, ecology, and epidemiology of the potato late blight pathogen Phytophthora infestans in soil. Phytopathology 85:1053-1056.

Bjor, T. 1987. Testing the resistance of potato cultivars to tuber blight. Potato Res. 30:525532.

Caten, C.E. and J.L. Jinks. 1968. Spontaneous variability of single isolates of Phytophthora infestans. I. Cultural variation. Can. J. Bot. 46:329-348.

Cooke, L.R. and G. Little. 2002. The effect of foliar application of phosphonate formulations on the susceptibility of potato tubers to late blight. Pest Mgt. Sci. 58:17-25.

Dorrance, A.E. and D.A. Inglis. 1998. Assessment of laboratory methods for evaluating potato tubers for resistance to late blight. Plant Dis. 82:442-446.

El-Bedewy, R., O.M. Olanya, P.T. Ewell, C. Lung'aho, P.S. Ojiambo, and J. Karinga. 2001. Evaluation of potato clones (Population $\mathrm{A}$ and $\mathrm{B}$ ) for resistance to late blight infection in Kenya. Afri. Crop Sci. J. 9:215-223.
Erwin, D.C. and O.K. Ribeiro. 1996. Phytophthora diseases worldwide. APS Press, St. Paul, MN.

Flier, W.G., L.J. Turkensteen, and A. Mulder. 1998. Variation in tuber pathogenicity of Phytophthora infestans in the Netherlans. Potato Res. 41:345-354.

Flier, W.G., L.J. Turkensteen, G.B.M. Van den Bosch, P.F.G. Vereijken, and A. Mulder. 2001. Differential interaction of Phytophthora infestans on tubers and potato cultivars with different levels of blight resistance. Plant Pathol. 50:292-301.

Fry, W.E. and S.B. Goodwin. 1997. Resurgence of the Irish potato famine fungus. Bioscience 47:384-416.

Glass, J.R., K.B. Johnson, and M.L. Powelson. 2001. Assessment of barriers to prevent the development of potato tuber blight caused by Phytophthora infestans. Plant Dis. 85:521528.

Grinberg, M., D. Kadish, and Y. Cohen. 1995. Infectivity of metalaxyl-sensitive and -resistant isolates of Phytophthora infestans to whole potato tubers as affected by tuber aging and storage. Phytoparastica 23:165175 .

Hirst, J.M., O.J. Stedman, J. Lacey, and G.A. Hide. 1965. The epidemiology of Phytophthora infestans: IV. Spraying trials 1959 to 1963 and infection of tubers. Ann. Appl. Biol. 55:373-395.

Jaetzold, R. and H. Schmidt. 1982. Farm management handbook of Kenya. Kenya and German Agricultural Team of the German Technical Co-operation, Ministry of Agriculture, Rossdolf, Germany.

Kirk, W.W., K.J. Felcher, D.S. Douches, B.A. Niemira, and R. Hammerschmidt. 2001. Susceptibility of potato (Solanum tuberosum L.) foliage and tubers to the US-8 genotype of Phytophthora infestans. Amer. J. Potato Res. 78:319-322.

Lacey, J. 1967. Susceptibility of potato tubers to infection by Phytophthora infestans. Ann. Appl. Biol. 59:257-264.
Lambert, D.H., A.I. Currier, and O.M. Olanya. 1998. Transmission of Phytophthora infestans in cut potato seed. Amer. J. Potato Res. 74:39-43.

Landeo, J.A., M. Gastelo, G. Forbes, J.L. Zapata, and F.J. Flores. 1995. Breeding for horizontal resistance to late blight in potato free of Rgenes, p. 268-274. In: Dowley, L.J., E. Bannon, L.R. Cooke, T. Keane, and E. O'Sullivan (eds.). Phytophthora infestans. 150 Boole Press, Dublin, UK.

Landeo, J.A. and L. Turkensteen. 1989. Assessment of partial resistance to late blight (Phytophthora infestans) of major genes in potato. Amer. Potato J. 66:530.

Lapwood, D.H. 1977. Factors affecting the field infection of potato tubers of different cultivars by blight (Phytophthora infestans). Ann. Appl. Biol. 85:23-42.

Mukalazi, J., E. Adipala, T. Sengooba, J.J. Hakiza, M. Olanya, and H.M. Kidanemariam. 2001. Metalaxyl resistance, mating type and pathogenicity of Phytophthora infestans in Uganda. Crop Prot. 20:379-388.

Nyankanga, R.O., H.C. Wien, O.M. Olanya, and P.S. Ojiambo. 2007. Relationship of foliar and potato tuber blight (Phytophthora infestans) as affected by foliage blight severity, cultivar resistance, atmospheric and soil variables. Can. J. Plant Pathol. 29:372-387.

Olanya, O.M., P.S. Ojiambo, and R.O. Nyankanga. 2006. Dynamics of development of late blight (Phytophthora infestans) in potato, and comparative resistance of cultivars in the highland tropics. Can. J. Plant Pathol. 28:84-94.

Parker, J.M., H.D. Thurston, M.J. Villrreal-Gozalez, and W.E. Fry. 1992. Stability of disease expression in potato late blight pathosystem. A preliminary field study. Amer. Potato J. 69:635644.

Peters, R.D., H.W. Platt, R. Hall, and M. Medina. 1999. Variation in the aggressiveness of Canadian isolates of Phytophthora infestans as indicated by their relative abilities to cause potato tuber rot. Plant Dis. 83:652661. 
Phatak, N. and D.D. Clarke. 1987. Studies on the resistance of the outer cortical tissues of the tubers of some potato cultivars to Phytophthora infestans. Physiol. Mol. Plant Pathol. 31:123-132.

Platt, H.W. and G. Tai. 1998. Relationship between resistance to late blight in potato foliage and tubers of cultivars and breeding selections with different resistance levels. Amer. J. Potato Res. 75:173-178.

Stevenson, W.R. 1993. Management of early blight and late blight, p. 141-147. In: Rowe, R.C. (ed.). Potato health management. APS Press, St. Paul, MN.
Stewart, H.E., J.E. Bradshaw, and R.L. Wastie. 1994. Correlation between resistance to late blight in foliage and tubers in potato clones from parents of contrasting resistance. Potato Res. 37:429-434.

Toxopeus, H.J. 1958. Some notes on the relation between field resistance of Phytophthora infestans in leaves and tubers and ripening time in Solanum tuberosum subsp. tuberosum. Euphytica 7:123-130.

Umaerus, V. and M. Umaerus. 1994. Inheritance of resistance to late blight, p. 365-402. In: Bradshaw, J.E. and G.R. Mackay (eds.). Potato genetics. CAB Publishing, CAB International, Wallingford, UK

Vega-Sanchez, M.E., L.J. Erselius, A.M. Rodiguez, O. Bastidas, H.R. Hohl, P.S. Ojiambo, J. Mukalazi, T. Vermuelen, W.E. Fry, and G.A. Forbes. 2000. Host adaptation to potato and tomato within the US-1 clonal lineage of Phytophthora infestans in Uganda and Kenya. Plant Pathol. 49:531-539.

Wastie, R.L. 1991. Breeding for resistance, p. 193 224. In: Ingram, D.S. and P.H. Williams (eds.). Advances in plant pathology. Vol. 7. Academic Press, London, UK. 